\title{
INFLUENCE BETWEEN LEARNING MOTIVATION AND STUDENTS' ANXIETY LEVEL ON MATHEMATICS LEARNING OUTCOMES OF VIII GRADE JUNIOR HIGH SCHOOL STUDENTS IN KALASAN SUBDISTRICT SLEMAN
}

\author{
Nanang iman Mochammad ${ }^{\mathrm{a}}$, Suparman ${ }^{\mathrm{b}}$ \\ Program studi pendidikan matematika FKIP UAD \\ Jln. Ringroad Selatan, Tamanan, Banguntapan, Bantul, Yogyakarta \\ ananangiman93@gmail.com, ${ }^{\mathrm{b}}$ suparman@pmat.uad.ac.id
}

\begin{abstract}
Students' motivation in Mathematics that is considered low and students' anxiety level are expected to influence the students' learning outcome. This research aims to discover whether there are effects or not towards the Mathematics' learning outcome between the high-motivated students in studying or the low ones and high anxiety level or low towards the students of the $8^{\text {th }}$ grade of the whole junior high schools in Kalasan sub-district, Sleman, Academic Year 2014/2015. The population in this research involves all students of the $8^{\text {th }}$ grade in Kalasan sub-district, Sleman, Academic Year 2014/2015 consisting of 20 classes whose students are 637. Samples in all schools were taken by using the Random Sampling technique towards classes in every school. The result is 3 classes, SMPN 1 Kalasan $8^{\text {th }} \mathrm{C}$ grade, SMPN 2 Kalasan $8^{\text {th }}$ D grade, and SMPN 4 Kalasan $8^{\text {th }} B$ grade as the experiment class whose students are 97. The collecting method used was a questionnaire for motivation and students' anxiety level, and also the students' learning outcome test method in Mathematics. The data analysis used two-way variance $2 \times 2$ with different cells and post ANOVA. The result of this research shows (1) The existence of study motivation's significant effect towards the Mathematics' learning outcome of students of SMPN $8^{\text {th }}$ grade for the whole Kalasan sub-district, Sleman, Academic Year 2014/2015 of Even Semester obtained t $\mathrm{t}_{\text {count }}$ > $t_{\text {table }}=9,48967>1,661$ at significance level of 5\%. (2) The existence of significant influence of students' anxiety level towards the Mathematics' learning outcome of the students in SMPN $8^{\text {th }}$ grade in all Kalasan sub-district, Sleman, Academic Year 2015/2015, Even Semester obtained $t_{\text {count }}>t_{\text {table }}$ is $-10,25663<1$, 661 at significance level of 5\%. (3) The absence of mutual influence between learning motivation and students' anxiety level on the Math's learning outcome of the students in SMPN $8^{\text {th }}$ grade in all Kalasan sub-district, Sleman, Academic Year 2015/2015, Even Semester obtained $\mathrm{f}_{\text {count }}<\mathrm{f}_{\text {table }}$ is $0,91<3,956$ at significance of level $5 \%$.
\end{abstract}

Keywords: motivation, anxiety, learning outcome.

\section{INTRODUCTION}

Related to the world of education, to create high-quality and high-achieving human beings students must have good learning achievements. Learning achievement is the maximum measure that has been achieved by students after doing learning actions during a predetermined time. In an educational institution, learning achievement is an important indicator to measure the success of the teaching and learning process. Education plays an important role in the process of improving learning achievement and the quality of human resources. Improving the quality of education is a process in order to improve the quality of human resources, especially in the world of education can be seen from the success that has been done. The human resources in question are students or students because students are a determining factor in the learning process obtained from the surrounding environment. Students as human resources in formal education are required to have adequate skills and abilities so that the knowledge acquired in schools can be used for themselves and the community.

The learning objectives expected by students are achieving good learning outcomes. One of them is the result of learning mathematics. Mathematics is one of the subjects studied until now, mathematics is also one of the compulsory subjects in national examinations, but most of the mathematics learning outcomes achieved by students are still relatively low. Even though there has been a lot done by teachers and schools so that the results of learning mathematics are better. Mathematical learning outcomes are feedback from the learning process of mathematics itself. The learning process that has been done by 
students can be concluded from the results. For example, those who have not understood become to understand and from those who do not know to know.

Based on the observations I did on November 10-15 in State Junior High Schools 1, 2, and 4 Kalasan, information was obtained from Mr. Suryantoro, S.Pd as a math teacher at Kalasan 1 Public Middle School that most students did not pay attention when the teacher was explaining the lesson and when given the assignment most students did not work, whereas according to the teachers in Kalasan 2 Public Middle School Sleman Regency on average students still consider that mathematics is a complicated lesson in understanding some of the problems contained in it, so that the results of student learning are still low, and according to Mr. Catur Haryadi, S.Pd, a teacher from Kalasan Middle School 4 that most students while attending classes still do not dare to ask questions or answer questions given directly by the teacher. Students tend to be quiet when they do not understand the material or questions that they are doing and ask their closest friends instead of asking directly to the teacher. Students feel afraid and anxious about the mistake of trying to work on the problem ahead and feel embarrassed if the problem is done wrong.

From these observations, there are several factors that are thought to influence the high and low student learning outcomes, some of which are learning motivation factors and students' anxiety levels towards learning outcomes that will be accepted by the students themselves. Increased learning motivation will certainly make students 'interest in mathematics high, and will have a positive impact on the students' mathematics learning outcomes. But student learning motivation can sometimes be weak, weak student learning motivation will certainly make student learning activities become weak as well. This will have an impact on the low quality of student learning outcomes. Therefore, learning motivation in students needs to be strengthened continuously. Another factor that affects learning outcomes is the level of student anxiety. Almost everyone has felt anxious, except that everyone's anxiety levels are different. At a moderate or normal level, anxiety can encourage someone to do better for the progress of his life. Conversely at high levels of anxiety can interfere with his soul.

Basically, anxiety that is felt is not necessarily happening, thus anxiety is actually a self-created fear. In almost everything, individuals who experience anxiety are always worried and afraid. So anxiety is a condition that results in someone feeling uncomfortable and completely wrong so that they cannot carry out activities optimally, this will certainly have a negative impact on the students' mathematics learning outcomes. Therefore, students must be able to reduce their anxiety so as not to interfere with their learning activities. Based on observations on November 10-15, 2014 in State Middle Schools 1 Kalasan, Kalasan Middle School 2 and Kalasan Middle School, data obtained from grade VIII odd semester UTS for the 2014/2015 school year as follows are shown in Table 1.

Table 1. List of Percentages of Mathematics UTS Values in Three Public Middle Schools in Kalasan District, Sleman Regency, 2014/2015 Academic Year

\begin{tabular}{|r|c|c|c|c|}
\hline No & School name & KKM & $\begin{array}{c}\text { Complete } \\
(\%)\end{array}$ & $\begin{array}{c}\text { Not } \\
\text { Complete } \\
(\%)\end{array}$ \\
\hline 1 & SMP N 1 Kalasan & 78 & 14,51 & 85,49 \\
\hline 2 & SMP N 2 Kalasan & 75 & 0 & 100 \\
\hline 3 & SMP N 3 Kalasan & 75 & 5,51 & 94,48 \\
\hline 4 & SMP N 4 Kalasan & 77 & 21,26 & 78,84 \\
\hline & Average & 76,25 & 10,32 & 89,68 \\
\hline
\end{tabular}

Table 1 shows that most students still have not reached the Minimum Completion Criteria (CCM) in each school. This proves that the mathematics learning outcomes of students are still relatively low.

According to Sardiman (2011: 75) motivation to learn is the overall driving force in students that gives rise to learning activities, which guarantees the continuity of learning activities and which gives direction to learning activities, so that the objectives desired by the subject of learning can be achieved. 
Whereas according to Uno, Hamzah (2007: 23) motivation to learn is internal and external encouragement to students who are learning to make behavioral changes. Based on the description above, it can be concluded that motivation is a change that is in someone who comes from internal and external encouragement to act, do something because there is a certain purpose.

According to Sardiman (2011: 89) what is meant is intrinsic motivation are motives that become active or functioning do not need to be stimulated from the outside because in each individual there is an urge to do something. Meanwhile, according to Hamalik, Oemar (2011: 112) intrinsic motivation is the motivation that is included in learning situations that are sourced from the needs and goals of the students themselves. From the above understanding, it can be concluded that intrinsic motivation is a motive that originates from within which allows each individual to do something that is sourced from the needs and goals of the individual itself.

According to Sardiman (2011: 89), extrinsic motivation is motives that are active and functioning because of the presence of stimulants from the outside. Whereas according to Hamalik Oemar (2011:112) extrinsic motivation is motivation caused by factors from outside the learning situation such as numbers, diplomas, levels, gifts, medals, opposition, and competition. From the above understanding, it can be concluded that extrinsic motivation is a motive that comes from outside that allows each individual to do something because of the factors outside the learning situation. Anxiety is a response to threats whose sources are unknown, vague, or conflictual (Kaplan, 1997: 3). Anxiety may be enlarged by the feeling of shame that others will be afraid of.

The experience of anxiety has two components, namely awareness of the presence of physiological sensations (such as palpitations and sweating), and consciousness being nervous or frightened (Kaplan, 1997: 4). Anxiety may be aggravated by the feeling of shame that his fear will be known to others. Many people are surprised to learn that other people do not know their anxiety or if someone else knows it, not paying attention to the degree of anxiety.

Anxiety affects perception, thinking and learning. Anxiety tends to produce confusion and distortion of perception, not only in space and time but also in people and the meaning of events. These distortions can interfere with learning by reducing the ability to focus attention, reduce memory, and interfere with the ability to connect one thing to another (Kaplan, 1997: 5) Atkinson (1996: 213) distinguish anxiety into three, namely:

1. Anxiety as an unconscious conflict. Feud was convinced that anxiety neuritis was a result of unconscious conflict between impulses (aggressiveness) with constraints on personal values or social values. Like anxiety caused by guilt, sin, serious and chronic ongoing emotional conflicts, frustration, and inner tension.

2. Anxiety as a response learned. Anxiety as a response is based on an unpleasant experience and every individual must have experienced it. This feeling is characterized by anxiety, confusion, worry, and fear. This is only felt and known by the person concerned.

3. Anxiety as a result of a lack of control. Anxiety experienced by someone when facing a situation that seems out of their control. For example, the anxiety of a student is facing a subject test that has not been mastered by the material.

Based on the background and limitations of the problem, then the problem can be formulated to be examined, namely is there any influence between learning motivation and students' anxiety level on mathematics learning outcomes of VIII grade SMP students in Kalasan Subdistrict, Sleman Semester District 2014/2015 Academic Year?

In connection with the formulation of the problem that has been described, the objectives to be achieved from this study are to determine whether or not there is an influence between learning motivation and students' anxiety level on mathematics learning outcomes of VIII grade junior high school students in Kalasan Subdistrict, Sleman Semester District Academic Year 2014/2015.

\section{METHODS}

This research is classified as quantitative research. The place of research was carried out in the Public Middle School in Kalasan District. While the time of the study was carried out in the even semester 
of the 2014/2015 school year. The population in this study were all eighth-grade students of the State Middle School in Kalasan Subdistrict, Sleman Even the 2014/2015 Academic Year as many as 637 students. Learning outcomes data are categorized into four groups, namely group 1 with high category learning motivation criteria and high-level anxiety level students, group 2 with high category learning motivation criteria and low level anxiety level students, group 3 with low category learning motivation criteria and student anxiety levels high category, and group 4 with low category learning motivation criteria and anxiety level of low category students.

In this study, samples were taken randomly using random sampling techniques for classes at each school. It was random because the sample taking was done randomly from the existing classes, because the preparation of the classes was random and those taken as sample classes were for SMP Negeri 1 Kalasan used class VIII C with the number of students as many as 33 children, SMP Negeri 2 Kalasan used class VIII D with the number of students as many as 32 children and SMP Negeri 4 Kalasan used and VIII B with a total of 32 students.

In this study, there are three variables, namely student learning motivation on mathematics subjects (A), student anxiety level (B), and student mathematics learning outcomes (X). Data collection techniques used questionnaires and test methods. In this study, the questionnaire method was used to obtain data on learning motivation and students' anxiety levels. The test method was used to obtain data on the mathematics learning outcomes of eighth-grade students of the State Middle School in Kalasan Subdistrict, Sleman Semester District 2014/2015 Academic Year. To find out the reliability of the questionnaire instrument used the Cronbach Alpha formula (Burhan, 2002: 330) as follows:

$$
r=\left(\frac{k}{(k-1)}\right)\left(1-\frac{\sum_{i=1}^{k} \sigma_{i}^{2}}{\sigma_{t}^{2}}\right)
$$

Variance is searched by the formula:

$$
\sigma_{i}^{2}=\frac{\sum_{j=1}^{n} X_{i j}^{2}-\frac{\left(\sum_{j=1}^{n} X_{i j}\right)^{2}}{N}}{N}
$$

Wherein:

$\mathrm{r} \quad=$ Reliability index

$\mathrm{k} \quad=$ Number of instrument items

$\sigma_{i}^{2} \quad=$ Item variance to-i, $\mathrm{i}: 1,2,3 \ldots \mathrm{k}$

$\sigma_{t}^{2} \quad=$ Total variance

$\mathrm{N} \quad=$ number of respondents

$\mathrm{X}_{\mathrm{ij}} \quad=$ score items for each individual to-j, $\mathrm{j}: 1,2,3, \ldots \mathrm{n}$

While the test instrument test uses the instrument validity test (Arikunto, 2010:213) with the product-moment with the formula:

$$
r_{x y}=\frac{n \sum_{i=1}^{n} x_{i} y_{i}-\left(\sum_{i=1}^{n} x_{i}\right)\left(\sum_{i=1}^{n} y_{i}\right)}{\sqrt{\left\{n \sum_{i=1}^{n} x_{i}^{2}-\left(\sum_{i=1}^{n} x_{i}\right)^{2}\right\}} \sqrt{\left\{n \sum_{i=1}^{n} y_{i}^{2}-\left(\sum_{i=1}^{n} y_{i}\right)^{2}\right\}}}
$$

Then different power tests were carried out, then tested the reliability of the instrument with the KR-20 formula, and the test of difficulty level. After the data is collected, an analysis prerequisite test that must be fulfilled includes the normality test and homogeneity test. Data analysis used two-way variance analysis with unequal cells and continued with the post-anova test.

\section{RESULTS AND DISCUSSION}

In this section, a further discussion of the results of the study with variance analysis found that there was an influence between students 'learning motivation on mathematics subjects and students' anxiety levels on mathematics learning outcomes. Based on the analysis of the data obtained from the experimental activities, the discussion of the results of the research and analysis is carried out, namely: 
1. There was a significant effect of learning motivation on the mathematics learning outcomes of students of Class VIII Middle School in Kalasan District, Sleman Regency, 2014/2015 Academic Year Even Semester. From the t-test conducted, the learning motivation variable toward learning outcomes was obtained, with a 5\% significance level obtained by $t_{\text {count }}=9,48967>t_{\text {table }}=1,994$, then concluded that the learning motivation variable on average in the high category was greater than the average in the category low. The results of testing the first hypothesis are relevant and in accordance with the theoretical study of student motivation on mathematics subjects that have a significant effect on mathematics learning outcomes.

2. There is a significant influence of students' anxiety level on the mathematics learning outcomes of students of Class VIII Middle School in Kalasan District, Sleman Regency 2014/2015 Academic Year Even Semester. From the t test, the students' anxiety level variables toward learning outcomes were obtained, with a significant level of $5 \%$ obtained $t_{\text {count }}=-10.25663<t_{\text {table }}=1.994$, it was concluded that the variable anxiety level of students in the lower category was greater than the average in the high category. The results of testing the second hypothesis are relevant and in accordance with the study of the theory of mathematics learning anxiety which has a significant effect on mathematics learning outcomes.

3. There is no joint influence between learning motivation and students' anxiety level on the mathematics learning outcomes of students of Class VIII Middle School in Kalasan District, Sleman Regency 2014/2015 Academic Year Even Semester. It can be seen that high learning motivation is better than low learning motivation with $t_{\text {count }}$ of 9,48967 . Whereas for the anxiety level variable with a $t_{\text {count }}$ of -10.25663 , it was found that the low anxiety level was better than the high anxiety level. While treatment 2 (high motivation and low anxiety) is the highest group with an average of 85.25, compared to Treatment 1 with an average of 73.75 , and treatment 3 with an average of 46.67 , and treatment 4 with an average of 62.35. The results of testing the third hypothesis are relevant and in accordance with the study of the theory which states that there is no joint influence between learning motivation and students' anxiety levels on mathematics learning outcomes.

\section{CONCLUSION}

Based on the results of the research and discussion as described above, it can be concluded that the students 'learning motivation in mathematics subjects and students' anxiety levels influence students 'mathematics learning outcomes and there is no joint influence between students' learning motivation on mathematics subjects and anxiety levels students towards the mathematics learning outcomes of students of class VIII Public Middle School in Kalasan District, Even Sleman Regency, 2014/2015 Academic Year.

\section{REFERENCES}

A.M., Sardiman. 2011. Interaksi \& Motivasi Belajar Mengajar. Jakarta: Raja Grafindo Persada.Feist, Jeist dan J, Feist Gregory. 2014. Teori Kepribadian. Jakarta: Salemba Humanika.

Arikunto, Suharsimi. 2010. ProsedurPenelitian Suatu Pendekatan Praktik. Jakarta: Rineka Cipta.

Atkinson dkk. 1996. Pengantar Psikologi. Cetakan ketiga. Jakarta: Erlangga.

B. Uno, Hamzah (2011). Teori Motivasi dan Pengukurannya Analisis Di Bidang Pendidikan. Jakarta : Bumi aksara.

Hamalik, Oemar. 2011. Kurikulum dan pembelajaran. Jakarta: Bumi Aksara.

Kaplan H.I, Sadock B.J, Grebb J. A. 1997. Sinopsis Psikiatri Jilid 1. Edisi ke-7. Terjemahan Widjaja Kusuma. Jakarta: Binarupa aksara. 